\section{Seed Priming Effect on Symbiotic Germination and Seedling Development of Orchis palustris Jacq.}

\author{
Ahmet Esitken ${ }^{1}$ and Sezai Ercisli \\ Department of Horticulture, Ataturk University, Faculty of Agriculture, 25240 \\ Erzurum, Turkey
}

Cafer Eken

Department of Plant Protection, Ataturk University, Faculty of Agriculture, 25240 Erzurum, Turkey

David Tay

Ornamental Plant Germplasm Center, The Ohio State University, 670 Vernon Tharp Street, Columbus, OH 43210

Additional index words. orchid, Orchidaceae, osmoconditioning

\begin{abstract}
Seeds of Orchis palustris Jacq. were primed for 1- to 5-day in polyethylene glycol (PEG-6000) solutions at $-\mathbf{0 . 5},-\mathbf{1 . 0}$ or $-1.5 \mathrm{MPa}$. The seeds were symbiotically germinated with BNR 8-3 mycorrhizal fungus on oatmeal agar at $22^{\circ} \mathrm{C}$. In general, priming hastened rapid germination. At $-1.5 \mathrm{MPa}$ water potential, the first to germinate was eight days compared to 18 days for the control. Percentage germination increased as priming water potential decreased, and the percentage germination was $55 \%, 58 \%$, and $65 \%$, at -0.5 , -1.0 , and $-1.5 \mathrm{MPa}$, respectively, versus $43 \%$ for the nonprimed control. Priming duration from 1 to 5 days had little effect on germination performance. The best germination percentage $(68 \%)$ was obtained from 1 day at -1.5 MPa treatment.
\end{abstract}

Seeds of terrestrial orchid are dust-like, minute $(0.07$ to $0.40 \mathrm{~mm}$ width and 0.11 to $1.97 \mathrm{~mm}$ length) and difficult to handle and germinate (Rasmussen, 1995). Orchid seeds do not have endosperm, and terrestrial orchid seeds require mycorrhizal fungi as an energy source (mycotrophy) in a symbiotic relationship (Rasmussen, 1995) to initiate seed germination and seedling development (Arditti et al., 1984). Unfortunately, only a few seeds out of millions produce this symbiotic relationship in nature (Arditti et al., 1984). In addition, in vitro symbiotic seed germination and seedling development is lower than those of many other angiosperm seeds (Markovina and McGee, 2000; Stewart and Zettler, 2002; Zettler and Hofer, 1998).

Seed priming, a process in which seeds are imbibed to a desired moisture content to arrest radicle emergence, followed by drying (McDonald, 2000), has resulted in more rapid and uniform germination in numerous plant species (Capron et al., 2000; Chen and Sung, 2001; Pill and Kilian, 2000). A range of osmotic substances has been used for priming seeds, including mannitol, glycerol, sucrose and inorganic salts of $\mathrm{K}, \mathrm{Na}$ and $\mathrm{Mg}$ (Heydecker and Coolbear, 1977; Parera and Cantliffe, 1994), but most studies have been conducted with polyethylene glycol (PEG), a high-molecular-weight organic compound (Capron et al., 2000; Pill and Kilian, 2000).

Received for publication 15 Oct. 2003. Accepted for publication 1 May 2004. This study was supported by The Prime Ministry, The State Planning Organization, Republic of Turkey.

${ }^{1}$ Corresponding author, e-mail aesitken@atauni. edu.tr.

1700
$5.25 \% \mathrm{NaOCl}$, and deionized (DI) water, followed by three 1-min rinses in sterile DI water. Then seeds were sown immediately according to the procedure described by Debeljak et al. (2002); 100 to 250 disinfested seeds for per petri dish were spread on the surface of $20 \mathrm{~mL}$ of oatmeal agar $\left(2.5 \mathrm{~g} \cdot \mathrm{L}^{-1}\right.$ rolled oats and 7.0 $\mathrm{g} \cdot \mathrm{L}^{-1}$ agar in $1 \mathrm{~L}$ DI water at $\mathrm{pH} 6.0$ before autoclaving at $121{ }^{\circ} \mathrm{C}$ for $15 \mathrm{~min}$ ) contained within 90-mm-diameter petri dishes. Each treatment was replicated five times. Each dish was then inoculated with about $1 \mathrm{~cm}^{3}$ block of agar containing mycelium of the BNR 8-3 isolate. The petri dishes were sealed with Parafilm and incubated in white light (warm white fluorescent) of $30 \mu \mathrm{mol} \cdot \mathrm{m}^{-2} \cdot \mathrm{s}^{-1}$ of $16 \mathrm{~h}$ photoperiod at constant $22 \pm 1{ }^{\circ} \mathrm{C}$ for $90 \mathrm{~d}$. Seed germination was monitored daily for first germination time. Seedling development were scored for a duration of $90 \mathrm{~d}$ on a scale of 0 to 5 , where $0=$ no germination; $1=$ production of rhizoid (i.e., germination); 2 = rupture of testa of the enlarged embryo; $3=$ appearance of promeristem; 4 = appearance of the first true leaf; and $5=$ elongation of the first true leaf and the formation of branched roots (Stewart and Zettler, 2002; Zettler and Hofer, 1998).

A germination $(G)$ index was calculated to take into consideration all the germinated seeds in different stages of seeding development (Scale 1 to 5) at the end of $90 \mathrm{~d}$. The formula used was as follows:

$\mathrm{G}$ index $=$ [germination \% of stage $1 \times 1$ (scale $1)+$ germination $\%$ of stage $2 \times 2($ scale 2$)+$ ....... + germination $\%$ of stage $5 \times 5$ (scale 5)]/100. applied to symbiotic germination of orchids. In the present study, we determined the effect of priming with different concentrations of PEG-6000 for varying periods on symbiotic seed germination and seedling development of Orchis palustris Jacq.

\section{Materials and Methods}

Seed and fungal collection. Mature, nondehisced yellowing capsules of Orchis palustris from the Erzurum district in Turkey were collected in June 2002. After collection, seeds were dried in air at room temperature and $50 \%$ to $55 \%$ relative humidity (RH) for $2 \mathrm{~d}$ and stored in sealed, sterile glass vials at $2{ }^{\circ} \mathrm{C}$ in total darkness for 9 months. BNR 8-3 mycorrhizal isolate, recovered from the root-like organs of native Dactylorhiza urvilleana in Artvin, Turkey, was used because of its effectiveness in inducing seed germination and seedling development of Orchis palustris.

Priming treatments. Seeds were imbibed in polyethylene glycol (PEG-6000) solutions at three water potentials $(-0.5,-1.0$, and -1.5 $\mathrm{MPa}$ ) according to Michel and Kaufmann (1973), for 1, 2, 3, 4, or $5 \mathrm{~d}$. The volume of PEG solutions used for imbibition was $3 \mathrm{~mL}$ in 50-mm-diameter petri dish. Seeds were kept in darkness during priming at $25 \pm 1{ }^{\circ} \mathrm{C}$. The imbibition solutions were not refreshed during incubation. Seeds were dried at $25 \pm 1^{\circ} \mathrm{C}$ after imbibition for $1 \mathrm{~d}$.

Seed sowing, fungal inoculation and germination assessment. Following priming, seeds were surface-sterilized for $1 \mathrm{~min}$ in a $1: 1: 1$ (by volume) mixture of absolute $\mathrm{EtOH}$,
Statistical analysis. The experimental design used was a completely randomized with five replications. Germination percentage, germination index, first germination time and seedling development data were analyzed using analysis of variance (ANOVA), and mean comparisons were made using Duncan's multiple range test and orthogonal contrast.

\section{Results and Discussion}

All primed seeds had greater germination and seedling development than nonprimed (control) seeds (Table 1). Germination percentages were increased to an average of $65 \%$ for all $-1.5 \mathrm{MPa}$ water potential treatments, $58 \%$ for all $-1.0 \mathrm{MPa}$ treatments, and $55 \%$ at all $-0.5 \mathrm{MPa}$ treatments compared to $43 \%$ in the control. Reducing the water potential to -1.5 MPa increased the germination index from 1.1 in the control to 2.1 . At -0.5 and $-1.0 \mathrm{MPa}$, the germination index averages were 1.6 and 1.7 , respectively. All priming treatments also induced faster germination (first to germinate) as compared to the nonprimed seeds (control), which took $18 \mathrm{~d}$ to germinate (Table 1). Seed priming with PEG-6000 at-1.5 MPa increased the germination rate $22 \%$ compared to the control.

The water potential of PEG treatments had significant effects on seedling development $(P<0.001$, Table 1$)$. There was no difference between the control and the $-0.5 \mathrm{MPa}$ treatments in seedling development (with score 5) but in the $-1.0 \mathrm{MPa}$ treatments there was an increase 
Table 1. Effects of seed priming on germination and seedling development of Orchis palustris

\begin{tabular}{|c|c|c|c|c|c|c|c|c|c|c|}
\hline \multirow{3}{*}{\multicolumn{2}{|c|}{$\begin{array}{l}\text { Priming } \\
\Psi(\mathrm{MPa}) \\
\text { duration (d) }\end{array}$}} & \multirow{3}{*}{$\begin{array}{l}\text { FGT }^{z} \\
\text { (d) }\end{array}$} & \multicolumn{6}{|c|}{ Seedling development (\%) } & \multirow{3}{*}{$\begin{array}{c}\text { Germination } \\
\text { (stages 1-5) } \\
(\%)\end{array}$} & \multirow{3}{*}{$\begin{array}{c}\text { Germinatior } \\
\text { index }\end{array}$} \\
\hline & & & \multicolumn{6}{|c|}{ Stage $^{y}$} & & \\
\hline & & & 0 & 1 & 2 & 3 & 4 & $5^{x}$ & & \\
\hline-0.5 & 1 & 15 & 46 & 0 & 25 & 12 & 12 & 6 & 55 & 1.6 \\
\hline-0.5 & 2 & 16 & 44 & 1 & 25 & 13 & 12 & 5 & 56 & 1.6 \\
\hline-0.5 & 3 & 13 & 44 & 0 & 27 & 14 & 9 & 6 & 56 & 1.6 \\
\hline-0.5 & 4 & 14 & 45 & 0 & 29 & 12 & 8 & 5 & 55 & 1.5 \\
\hline-0.5 & 5 & 17 & 44 & 0 & 28 & 14 & 9 & 5 & 56 & 1.6 \\
\hline Mean & & $15 \mathrm{a}^{\mathrm{w}}$ & & & & & & $5.6 \mathrm{c}$ & $55.4 \mathrm{~b}$ & $1.59 \mathrm{c}$ \\
\hline-1.0 & 1 & 12 & 42 & 0 & 20 & 16 & 16 & 6 & 58 & 1.8 \\
\hline-1.0 & 2 & 11 & 41 & 1 & 29 & 13 & 11 & 6 & 59 & 1.7 \\
\hline-1.0 & 3 & 8 & 44 & 0 & 22 & 14 & 12 & 8 & 56 & 1.8 \\
\hline-1.0 & 4 & 10 & 42 & 0 & 22 & 15 & 12 & 8 & 58 & 1.8 \\
\hline-1.0 & 5 & 9 & 43 & 1 & 27 & 15 & 10 & 6 & 57 & 1.7 \\
\hline Mean & & $10 \mathrm{~b}$ & & & & & & $6.8 \mathrm{~b}$ & $57.7 \mathrm{~b}$ & $1.75 \mathrm{~b}$ \\
\hline-1.5 & 1 & 7 & 32 & 0 & 16 & 19 & 17 & 17 & 68 & 2.4 \\
\hline-1.5 & 2 & 7 & 35 & 1 & 17 & 16 & 19 & 13 & 65 & 2.2 \\
\hline-1.5 & 3 & 8 & 33 & 0 & 16 & 20 & 21 & 10 & 67 & 2.3 \\
\hline-1.5 & 4 & 8 & 35 & 0 & 24 & 19 & 15 & 7 & 65 & 2.0 \\
\hline-1.5 & 5 & 10 & 39 & 0 & 24 & 16 & 13 & 8 & 61 & 1.9 \\
\hline Mean & & $8 c$ & & & & & & $10.9 \mathrm{a}$ & $65.4 \mathrm{a}$ & $2.15 \mathrm{a}$ \\
\hline Contr & & 18 & 57 & 1 & 16 & 7 & 9 & 5 & 43 & 1.1 \\
\hline LSD 0 & & 1.73 & & & & & & 0.43 & 2.43 & 0.05 \\
\hline \multicolumn{11}{|c|}{$\Psi(\mathrm{MPa})$} \\
\hline & & $* * *$ & & & & & & $* * *$ & $* * *$ & $* * *$ \\
\hline & dratic & $*$ & & & & & & $*$ & $* * *$ & $* * *$ \\
\hline \multicolumn{11}{|c|}{ Priming duration (d) } \\
\hline & & NS & & & & & & $* *$ & NS & * \\
\hline & dratic & NS & & & & & & NS & NS & NS \\
\hline & & NS & & & & & & NS & NS & NS \\
\hline & rtic & NS & & & & & & NS & NS & NS \\
\hline
\end{tabular}

${ }^{\mathrm{z} F G T}=$ first germination time.

${ }^{\mathrm{y}}$ Scale 0 to 5 , where $0=$ no germination, $1=$ production of rhizoid (i.e., germination), $2=$ rupture of testa of enlarged embriyo, $3=$ appearance of promeristem, 4 = appearance of first true leaf, 5 = elongation of the first true leaf and formation of branched root.

xPercentage of advanced seedling at $90 \mathrm{~d}$ after sowing.

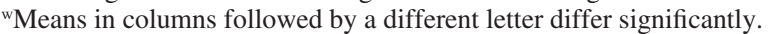

NS,********N Nonsignificant or significant at $P<0.05,0.01$, or 0.001 , respectively.

of $29 \%$ and in the $-1.5 \mathrm{MPa}$ treatments $106 \%$ as compared seedlings with elongated first true leaf and branched roots from the control seeds (Table 1)

This is the first published study to demonstrate that seed priming can increase symbiotic germination and seedling development in orchid species such as Orchis palustris. Ali et al. (1990) reported that extending priming duration from 1 to $4 \mathrm{~d}$ at $-0.58 \mathrm{MPa}$ increased germination percentages, but decreasing water potential of PEG-8000 solution to $-1.49 \mathrm{MPa}$ decreased germination percentage in tomato (Lycopersicon esculentum L.) and onion (Allium cepa L) seeds. Danneberger et al. (1992) studying ryegrass found that decreasing water potential of PEG- 8000 solutions from -0.1 to $-1.1 \mathrm{MPa}$ increased germination percentage, but at -1.2 and $-1.4 \mathrm{MPa}$, germination percentage decreased. In another study, Durrant et al. (1983) found no differences in sugar beet seed response to osmopriming using salt, as long as the osmotic potential of the salt solution was in the range of -1.0 to $-2.0 \mathrm{MPa}$. In general, Khan (1992) reported that water potentials between -0.8 and $-1.6 \mathrm{MPa}$ gave optimal germination in many plant species.

There is little information on the effect of seed priming on orchid germination and seedling development. The beneficial effects of priming may be attributed to the softening of the seed coat, reduction of the seed coat adherence, or the enhancement of enzyme activities in various plant species (Chen and Sung, 2001).
In conclusion, seed priming of Orchis palustris had positive effects on symbiotic germination. Priming at low water potentials $(-1.5 \mathrm{MPa})$ with PEG-6000 solution for short priming durations (1 to 3 days) under in vitro conditions reduced the time to first germination, and improved final germination rate and orchid seedling development.

\section{Literature Cited}

Ali, A., V.S. Machado, and A.S. Hamill. 1990 Osmoconditioning of tomato and onion seeds. Scientia Hort. 43:213-224.

Arditti, J., M. Arditti, and R. Ernst. 1984. Some structural and physiological features which facilitate the survival of orchids, p. 102-105. Proc. $11^{\text {th }}$ World Orchid Conf.

Capron, I., F. Corbineau, F. Dacher, C. Job, D. Come, and D. Job. 2000. Sugarbeet seed priming: effects of priming conditions on germination, solubilization of 11-S globulin and accumulation of LEA proteins. Seed Sci. Res. 10:243-254.

Chen, C.C. and J.M. Sung. 2001. Priming bitter gourd seeds with selenium solution enhances germinability and antioxidative responses under sub-optimal temperature. Physiologia Plantarum 111:9-16.

Danneberger, T.K., M.B. McDonald, Jr., C.A. Geron, and P. Kumari. 1992. Rate of germination and seedling growth of perennial ryegrass seed following osmoconditioning. HortScience 27:28-30.

Debeljak, N., M. Regvar, K.W. Dixon, and K. Sivasithamparam. 2002. Induction of tuberisation in vitro with jasmonic acid and sucrose in an Australian terrestrial orchid, Pterostylis sanguinea.
Plant Growth Regulat. 36:253-260.

Durrant, M.J., P.A. Payne, and J.S. McLaren. 1983. The use of water and some inorganic salt solutions to advance sugar beet seed. I. Laboratory studies. Ann. Biol. 103:507-515.

Heydecker,W.andP.Coolbear. 1977. Seed treatments for improved performance-survey and attempted prognosis. Seed Sci. Technol. 5:353-425.

Khan, A.A. 1992. Preplant physiological seed conditioning. Hort. Rev. 13:131-181.

Markovina, A-L. and P.A. McGee. 2000. Comparison of symbiotic and asymbiotic seed germination and plantlet development in Sarcochilus (Vandeae; Orchidaceae). Lindleyana 15:68-72.

McDonald, M.B. 2000. Seed priming, p. 287-325. In: M. Black and J.D. Bewley (eds.). Seed technology and its biological basis. Sheffield Acad. Press, Sheffield, U.K.

Michel,B.E. and M.R. Kaufmann. 1973. The osmotic potential of polyethylene glycol 6000. Plant Physiol. 51:914-916

Parera, C.A. and D.J. Cantliffe. 1994. Presowing seed priming. Hort. Rev. 16:109-141.

Pill, W.G. and E.A. Kilian. 2000. Germination and emergence of parsley in response to osmotic or matric seed priming and treatment with gibberellin. HortScience 35:907-909.

Rasmussen, H.N. 1995. Terrestrial orchids: From seed to mycotrophic plant. Cambridge Univ. Press, Cambridge, U.K.

Stewart, S.L. and L.W. Zettler. 2002. Symbiotic germination of three semi-aquatic rein orchids (Habenaria repens, H. quinquiseta, H. macroceratitis) from Florida. Aquatic Bot. 72:25-35.

Zettler, L.W. and C.J.Hofer. 1998. Propagation of the little club-spur orchid (Platanthera clavellata) by symbiotic seed germination, and its ecological implications. Environ. Expt. Bot. 39:189-195. 